\title{
Effect of the Continuity and Sampling Rate of Polygraphy Data on Sleep Stage by a Computerized Scoring System
}

\author{
-A Reliability Study-
}

\author{
Tomoyuki Kawada, Yasuo Kiryu, Seiichi Naganuma, \\ Shigenobu Aoki and Shosuke Suzuki \\ Department of Public Health, Gunma University School of Medicine, Maebashi
}

\section{Introduction}

Standardized techniques and scoring systems for sleep stages were reported in 1968 by Rechtschaffen and Kales $(\mathrm{R}-\mathrm{K})^{1)}$, and are now widely used for visual judgment of sleep polygraphy. Various computerized scoring systems for sleep stage have been developed during the past two decades to save time and energy . Such systems achieve reliability exceeding that by visual judgment of polygraphy ${ }^{2 \sim 4)}$, but they are not readily available due to various problems pointed out by the American Sleep Disorders Association ${ }^{5)}$.

In spite of this situation, recent advances in computer technology give computerized scoring systems advantages in reliability for sleep stage data analysis. In addition, estimation of percentages of alpha and delta waves per epoch are almost impossible by visual judgment. The present authors have also developed a computerized scoring system for sleep stage to assess the effect of noise on human sleep ${ }^{6}$.

The present study verifies the validity of the computerized system devised by the authors for determining sleep stage using four types of sampling data and visual judgment.

\section{Methods}

Six healthy male students in their twenties participated in the experiment. Five sleep polygraphs were recorded for each subject and were individually compiled into one, excluding the intra-individual variation. Drug intake and napping were not permitted.

Electroencephalogram (EEG) electrodes were positioned according to the international 10-20 method $(\mathrm{C} 3-\mathrm{A} 2)^{1)}$. The EEG, electromyogram (EMG) at the submental muscle, and electrooculogram (EOG) at the outer eye canthi were recorded using the telemetry system of NIHON KOHDEN Co. Ltd. (model WEE-6112). Sleep stage classification categories were stages 1, 2, 3, 4 and rapid eye movement (REM) in each epoch, according to the sleep EEG atlas of $\mathrm{R}-\mathrm{K}^{1}{ }^{1}$. Waking and movement time (MT) were also scored.

Signals of the EEG, EMG, and EOG, after being converted to digital data, were sampled at 100 $\mathrm{Hz}$. The data were entered on a 40 megabyte hard disk of a micro-computer (EPSON 286VS: 16 bit CPU with $16 \mathrm{MHz}$ clock speed). One epoch was 20 seconds. The integral voltage of the EMG, rapid eye movement, number of spindle waves, and percentage of alpha and delta (frequency less than $2 \mathrm{~Hz}$ and amplitude over 75 microvolts) waves were determined based on digital data using our computerized system $^{6}$. In this system, some modification of the sampling period was done. That of the first version was one-third of each minute (the first 20 seconds), while that of the second one was continuous. This was possible through use of an advanced analog/digital converter with a "first-in first-out", or FIFO, buffer memory (8 channel and 12 bit binary; ADM-1498BPC ${ }^{\circledR}$ Microscience Co. LTD, Japan). FIFO enables the simultaneous input and output of data.

Each subject slept in an experimental room not shielded electrically. Kappa statistics, the agreement rate of sleep stage, and percentage of each sleep stage against total sleep time were calculated for 
comparison of computerized data of different sampling periods and those of visual ones. Two tailed paired t-tests were used for statistical analysis.

\section{Results}

The percentages of agreement of the sleep stage for visual and computerized judgment using continuous data, one-third or one epoch per minute, one-ninth or one epoch per 3 minutes, and one-fifteenth or one epoch per 5 minutes, were compared. There was no difference in agreement between visual and computerized judgment using continuous data or one-third epoch per minute. There was a significant loss of agreement between visual and computerized judgment using one-ninth or one-fifteenth data compared with agreement between visual and computerized judgment using continuous data. The same tendencies were apparent when using Kappa statistics (Table 1).

Each stage percentage against total sleep time of visual and that of computerized judgment using continuous, one-third, one-ninth, or one-fifteenth sampling data was compared (Table 2-6). The percentages of stages 1, 2, 3, 4 and REM by computerized judgment showed no difference from visual judgment for any sampling period. The percentages of stages 3 and 4 by computerized judgment were quite similar to those of visual judgment, which may reflect the avoidance of a rule for smoothing of sleep stage by the standard method.

Table 1 Sleep stage agreement $(\%)$ between visual and computerized judgments of different sampling periods using 30 -night data from six subjects. Kappa values are also listed in parenthesis

\begin{tabular}{cccccc}
\hline Subjects & $\begin{array}{c}\text { Compiled } \\
\text { epoch num. }\end{array}$ & Continuous & One-third & One-ninth & One-fifteenth \\
\hline AH & 7379 & $82.5(.704)$ & $80.5(.679)$ & $77.4(.643)$ & $75.3(.611)$ \\
YM & 6684 & $79.1(.681)$ & $76.9(.654)$ & $69.0(.557)$ & $73.5(.626)$ \\
MH & 7109 & $78.6(.666)$ & $76.3(.635)$ & $73.2(.599)$ & $69.8(.554)$ \\
HS & 6801 & $70.3(.604)$ & $71.5(.629)$ & $70.1(.619)$ & $66.1(.564)$ \\
MY & 7125 & $83.0(.759)$ & $80.1(.720)$ & $74.9(.657)$ & $71.7(.617)$ \\
MS & 6287 & $77.0(.649)$ & $76.4(.646)$ & $76.0(.643)$ & $72.7(.598)$ \\
\hline Total & 41385 & $78.5(.680)$ & $77.0(.664)$ & $73.5(.624)$ & $71.5(.598)$ \\
\hline \multicolumn{2}{r}{ Test result } & & n.s. & $\mathrm{p}<0.05$ & $\mathrm{p}<0.01$ \\
\hline
\end{tabular}

num.: mumber, n.s.: not significant

Five-night data were compiled together for each subject.

Comparison was made between continuous and one-third, one-ninth, or one-fifteenth sampling data using a two-tailed paired t-test.

Table 2 Percentage of sleep stage 1 by visual and computerized judgments of different sampling times using 30-night data from six subjects

\begin{tabular}{cccccc}
\hline Subjects & Visual & Continuous & One-third & One-ninth & One-fifteenth \\
\hline AH & 9.2 & 11.6 & 13.6 & 19.2 & 21.2 \\
YM & 7.1 & 6.2 & 8.1 & 16.5 & 14.0 \\
MH & 9.5 & 5.2 & 6.3 & 11.4 & 21.6 \\
HS & 8.4 & 2.9 & 9.3 & 14.1 & 14.3 \\
MY & 15.2 & 7.3 & 11.2 & 18.8 & 24.7 \\
MS & 10.1 & 2.5 & 4.4 & 6.0 & 3.9 \\
\hline Total & 10.0 & 6.1 & 8.9 & 14.6 & 17.0 \\
\hline \multicolumn{2}{r}{ Test result } & n.s. & n.s. & n.s. & n.s. \\
\hline
\end{tabular}

n.s. : not significant

Five-night data were compiled together for each subject.

The percentages of sleep stage were calculated as the time of the corresponding stage divided by total sleep time, excluding waking and movement time.

Comparison was made between visual and continuous, one-third, one-ninth, or one-fifteenth sampling data using a two-tailed paired $t$-test. 
Table 3 Percentage of sleep stage 2 by visual and computerized judgments of different sampling times using 30-night data from six subjects

\begin{tabular}{cccccc}
\hline Subjects & Visual & Continuous & One-third & One-ninth & One-fifteenth \\
\hline $\mathrm{AH}$ & 65.9 & 68.0 & 64.4 & 59.4 & 60.3 \\
$\mathrm{YM}$ & 63.7 & 60.6 & 58.3 & 51.2 & 53.0 \\
$\mathrm{MH}$ & 59.8 & 64.3 & 62.2 & 58.9 & 58.3 \\
$\mathrm{HS}$ & 44.2 & 59.4 & 52.5 & 47.1 & 50.2 \\
$\mathrm{MY}$ & 48.3 & 55.1 & 52.7 & 46.2 & 44.7 \\
$\mathrm{MS}$ & 59.9 & 70.1 & 68.7 & 66.3 & 63.4 \\
\hline Total & 57.1 & 62.8 & 59.6 & 54.7 & 54.8 \\
\hline \multicolumn{2}{r}{ Test result } & $\mathrm{n} . \mathrm{s.}$ & $\mathrm{n} . \mathrm{s}$. & $\mathrm{n} . \mathrm{s}$. & $\mathrm{n} . \mathrm{s}$. \\
\hline
\end{tabular}

Abbreviations and comments are the same as in Table 2.

Table 4 Percentage of sleep stage 3 by visual and computerized judgments of different sampling times using 30 -night data from six subjects

\begin{tabular}{cccccc}
\hline Subjects & Visual & Continuous & One-third & One-ninth & One-fifteenth \\
\hline AH & 3.7 & 3.7 & 3.9 & 4.3 & 4.1 \\
YM & 8.7 & 8.6 & 8.9 & 9.7 & 9.8 \\
MH & 9.1 & 8.4 & 8.7 & 8.3 & 8.9 \\
HS & 20.3 & 17.8 & 17.8 & 18.8 & 16.7 \\
MY & 10.3 & 10.5 & 10.8 & 9.8 & 9.6 \\
MS & 7.2 & 6.6 & 7.1 & 7.4 & 8.7 \\
\hline Total & 9.7 & 9.3 & 9.5 & 9.7 & 9.6 \\
\hline \multicolumn{2}{r}{ Test result } & n.s. & n.s. & n.s. & n.s.
\end{tabular}

Abbreviations and comments are the same as in Table 2.

\section{Discussion}

The three-minute rule for stage 2 developed by $\mathrm{R}-\mathrm{K}$ should result in a smaller stage shift by taking an epoch with no spindle and slow wave in stage 2 . Correction of REM continuity also results in increased percent of stage REM. In this experiment, no prominent change of stage 2 and REM due to differences in sampling period was recognized.

Compared with the visual judgment, our computerized system does not include an MT correction for waking on sleep latency period or intra-sleep wakefulness. The percentage of waking plus MT was almost the same for visual and computerized judgment in each sampling period, and thus had no effect on the percentage of sleep stage.

The authors compared the percentages of sleep stages for visual and computerized judgment based on continuous, one-third, one-ninth, and one-fifteenth data. No statistical differences in the percentages of each stage judged by computer could be found for any sampling periods compared with visual judgment.

Subjects were six young male students in this experiment. Thus, factors of gender and age could be excluded, and also intra-individual change by the summation of data. Relatively large inter-individual differences were also accounted for by using a paired $-t$ test. From the results of stage agreement (Table 1), one-third sampling appears to be acceptable for sleep stage judgment.

\section{Summary}

The percentage of each sleep stage determined by visual judgment was compared with computerized judgment using continuous and three intermittent sampling data. Comparison of stage agreements of four types of computerized judgments with visual judgment were also conducted. Hypnograms of six healthy young male students were recorded on each of five nights. Data of each subject were compiled 
Table 5 Percentage of sleep stage 4 by visual and computerized judgments of different sampling times using 30-night data from six subjects

\begin{tabular}{cccccc}
\hline Subjects & Visual & Continuous & One-third & One-ninth & One-fifteenth \\
\hline AH & 0.2 & 0.2 & 0.2 & 0.1 & 0 \\
YM & 0.9 & 0.9 & 1.0 & 0.8 & 1.0 \\
MH & 1.2 & 1.1 & 1.1 & 1.1 & 0.7 \\
HS & 12.4 & 10.6 & 10.2 & 10.3 & 10.2 \\
MY & 6.1 & 6.1 & 5.8 & 6.7 & 6.2 \\
MS & 0.7 & 0.6 & 0.5 & 0.2 & 0.8 \\
\hline Total & 3.5 & 3.3 & 3.2 & 3.3 & 3.2 \\
\hline \multicolumn{7}{r}{ Test result } & n.s. & n.s. & n.s. & n.s.
\end{tabular}

Abbreviations and comments are the same as in Table 2.

Table 6 Percentage of sleep stage REM by visual and computerized judgments of different sampling times using 30-night data from six subjects

\begin{tabular}{cccccc}
\hline Subjects & Visual & Continuous & One-third & One-ninth & One-fifteenth \\
\hline AH & 20.9 & 16.5 & 18.0 & 17.0 & 14.4 \\
YM & 19.5 & 23.7 & 23.6 & 21.9 & 22.2 \\
MH & 20.5 & 21.1 & 21.7 & 20.4 & 10.5 \\
HS & 14.8 & 9.4 & 10.3 & 9.6 & 8.6 \\
MY & 20.1 & 21.0 & 19.6 & 18.4 & 14.9 \\
MS & 22.0 & 20.1 & 19.3 & 20.1 & 23.2 \\
\hline Total & 19.7 & 18.6 & 18.7 & 17.8 & 15.4 \\
\hline \multicolumn{7}{r}{ Test result } & n.s. & n.s. & n.s. & n.s. \\
\hline
\end{tabular}

REM: rapid eye movement

Other abbreviations and comments are the same as in Table 2.

individually, and the six data were analyzed.

Agreement rate of the sleep stage by computerized judgment using continuous (method A), one-third (method B), one-ninth (method C), and one-fifteenth (method D) data with that of visual judgment were compared. The agreement rate of visual and computerized judgment using method A showed no difference from that between visual and computerized judgment using method B. There was a significant loss of agreement between visual and computerized judgment using method $\mathrm{C}$ or $\mathrm{D}$ compared with that between visual and computerized judgment using method A.

Paired $t$-tests were conducted for each stage percentage against total sleep time of visual judgment and those of computerized judgments using method A, B, C, or D. There were no significant changes in any sleep stage percentages between visual judgment and computerized judgments using method A, $\mathrm{B}, \mathrm{C}$, or D.

From sleep stage agreement and the degree of difference from visual judgment, the acceptable limitation of the sampling period was concluded to be one-third of continuous data.

\section{References}

1) Rechtschaffen, A. and Kales, A. (eds): A manual of standardized terminology, techniques and scoring system for sleep stages of human subjects, Public Health Service, U.S. Government Printing Office, Washington D.C. (1968).

2 ) Hoelscher, T.J., McCall, W.V., Powell, J., Marsh, G.R. and Erwin, C.W.: Two methods of scoring sleep with the Oxford Medilog 9000: Comparison to conventional paper scoring, Sleep, 12, 133-139 (1989).

3 ) Kubicki, S., Holler, L., Berg, I., Pastelak-Price, C. and Dorow, R. : Sleep EEG evaluation: A comparison of results obtained by visual scoring and automatic analysis with the Oxford sleep 
stager, Sleep, 12, 140-149 (1989).

4) Ferri, R., Ferri, O., Colognola, R.M., Petrella, M.A., Musumeci, S.A. and Bergonzi, P.: Comparison between the result of an automatic and a visual scoring of sleep EEG recordings, Sleep, 12, 354-362 (1989).

5 ) Roffwarg, H.P. : ASDA position statement. Automatic scoring, Sleep, 13, 284-285 (1990).

6 ) Aoki, S. , Kawada, T., Takeuchi, K., Ogawa, M. and Suzuki, S.: Effects of noise on sleep. Part 1 Development of an automatic analysing system for all-night sleep polygraphy by microcomputer, Jpn. J. Hyg. , 43, 1092-1101 (1989). (in Japanese)

(Received December 26, 1991/Accepted May 26, 1992)

\title{
コンピュータ判定システムによるポリグラフィ・データの 連続性と採取率が睡眠段階に及ぼす影響
}

\author{
一信頼性の検討一 \\ 川田智之, 桐生康生, 長沼誠一, \\ 青 木 繁 伸, 鈴 木 庄 亮 \\ 群馬大学医学部公衆衛生学教室
}

騒音が睡眠に及ぼす影響を検討するために我々が開発した睡眠段階判定システムを用いて，連続的採取データおよび 三つの間歇的な採取データによる各睡眠段階の割合をコンピュータ判定し，視察によるそれと比較した。さらに視察判 定との一致率をデータ採取頻度との関連で検討した。既報の判定システム(日衛誌, 43, 1092-1101 (1989))では每分は

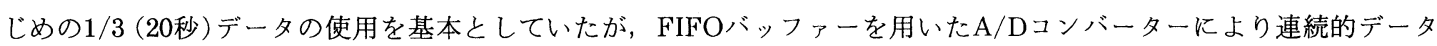
採取が可能となった。

心身ともに健常な 20 歳前半の学生 6 名について, 各 5 夜合計 30 夜分のヒプノグラムが実験室で記録された。1エポッ ク 20 秒として睡眠段階を判定した。各被験者 5 夜分のデータをとれぞれ 1 つに併せて, 視察判定による睡眠段階と，1） 連続的データ，2）1/3データ（毎分はじめの 1 エポック），3）1/9データ（3 分に 1 エポック），4） $1 / 15$ データ（5 分に 1 エポック)との各睡眠段階の一致率を 6 人の対応のあるデータとして両側 $\mathrm{t}$ 検定したが，連続的データと比較して $1 / 3$ デー 夕は視察判定との一致率に違いはなく，71.5 80.5\%であった。また，1/9データと視察判定との一致率は69.0 77.4 $\%, 1 / 15$ データと視察判定との一致率は66.1 75.3\%で統計的有意差を認めた(各々 $\mathrm{P}<0.05, \mathrm{P}<0.01$ )。なお，カッパ統 計値による一致度の検討でも同様の傾向を認めた。

次に視察判定による全睡眠時間(覚醒期および運動時間は除く)に対する各睡眠段階 $(1,2,3,4, R E M)$ 出現割合と, 連続的， $1 / 3,1 / 9$ ，および $1 / 15$ データのコンピュータ判定によるそれらとを 6 人の対応のあるデータとして比較した。 その結果, 視察判定による各睡眠段階出現割合は, 連続的採取データおよび三つの間歇的な採取データのコンピュータ 解析によるそれらと統計的有意差を認めなかった。

視察判定との睡眠段階の一致率の比較から，コンピュータ判定のためのデータは少なくとも全データの $1 / 3$ 必要で あると結論された。

Key words : Sleep stage, Computerized scoring system, Continuity of sampling data 睡眠段階, コンピュータ判定システム, 採取データの連続性 